\title{
Cadar dan Aturan Berpakaian Dalam Perspektif Syariat Islam
}

Oleh

\section{Hasiah}

Dosen Fakultas Syariah dan Ilmu Hukum IAIN Padangsidimpuan email : hasiah@iain-padangsidimpuan.ac.id

\begin{abstract}
Abstrac
The purpose of this study are: 1) Knowing the nature of the veil, 2) Knowing the history of the emergence of veils in the culture of Islamic society, 3) Knowing the perspective of Islamic law on the use of veils. This type of research is a literature study (Library Research), the object in this study is the concept of veil in the perspective of sharia based on the Qur'an and hadith, the veil controversy in the culture of society. Data is collected by quoting, analyzing using the legal and historical approach methods that occur regarding the use of veils in people's lives.

So the veil is a part of sharia after Islam came which was brought by the Prophet Muhammad. And it is also a culture that has occurred for generations before the existence of Islam (jahiliyah period).
\end{abstract}

Kata Kunci; Cadar, Perspektif, dan Syariah

\section{A. Pendahuluan}

Ajaran Islam adalah merupakan ajaran agama yang bersifat universal, yang aturanaturan Islam yang bersifat universal tersebut bisa dijumpai didalam kitab suci al-Qur'an yang mengandung pedoman dan petunjuk untuk kemaslahatan umat manusia dalam rangkah menggapai kesalamatan di dunia dan di akhirat. Islam adalah ad-din (agama) yang diturunkan Allah SWT kepada Nabi Muhammad SAW sebagai pedoman bagi manusia dalam mengatur hubungan manusia dengan Allah SWT, dengan dirinya sendiri dan dengan sesamanya. Termasuk mengenai pedoman berpakaian juga diatur dalam ajaran Islam, bahkan lebih dalam Islam pakaian seseorang dianggap sebagai salah satu ungkapan ketaatan (kepatuhan) seseorang kepada Allah SWT, karena itulah dalam ajaran Islam bahwa berpakaian bagi Muslimah memiliki nilai ibadah dan pahala bagi yang mengenakannya sesuai dengan syariat yang telah ditentukan. Maka dalam berpakaian, seorang Muslimah harus mengikuti aturan yang telah ditentukan Allah SWT dalam al-Qur'an. ${ }^{1}$

Sekalipun, dari berpakaian seseorang sesungguhnya tidaklah bisa menjadi petunjuk tentang kepribadian seseorang secara mutlak, akan tetapi sedikit dari pakaian yang 
digunakan seseorang sepintas akan dapat menggambarkan kepribadian seseorang, bahkan pakaian yang dikenakan seseorang bisa mempengaruhi lawan bicara sebab kepribadian pakaian yang sesuai dengan tuntutunan al-Qur'an akan memancarkan gambaran baik dan kesempurnaan diri seseorang. Oleh karena itu, Islam memberikan arah dan aturan tenantang pakaian apa saja yang boleh dipakai dan bagaimana cara berpakaian sebagaimana ditegaskan Allah SWT dalam surah an-Nur ayat 31 yang disebutkan dengan istilah khimar yang berbunyi sebagai berikut "Katakanlah kepada perempuan yang beriman: "Hendaklah mereka menahan penglihatannya, dan kemaluannya, dan janganlah mereka memperlihatkankan perhiasannya, kecuali yang (biasa) terlihat dari padanya. Dan hendaklah mereka menjulurkan khimar kedadanya..." "khumur adalah jamak dari khimar, dijulurkan ke dada-dada mereka sehingga tertutuplah rambut, leher dan anting-anting mereka.”

Aturan berpakaian tersebut di atas, adalah merupakan konsekuensi bagi setiap Muslim yang benar-benar mengaku beriman kepada Allah SWT dan Rasulullah SAW akan ada konsekuensi. Sebab dalam Islam, sudah menjadi konsekuensi logis bagi seluruh umat Islam supaya selalu menjadikan akidahnya sebagai landasan dalam berfikir dan bertindak, agar selalu berfikir Islami yaitu menilai segala sesuatu dari sudut pandang akidah Islam atau menilai segala sesuatu dengan standar syariah yakni mengenai halal (kebolehannya) atau haramnya (ketidak bolehannya) misalnya menilai halal jual beli dengan cara yang syariah dan mengharamkan jual beli dalam bentuk riba, memandang halal pernikahan dan mengharamkan perzinahan, serta menganggap kerudung ( jilbab) wajib bagi setiap Muslimah dan sebagainya.

Begitu juga dalam berprilaku, bahwa seorang Muslim harus terus berupaya berprilaku secara islami dengan artian selalu berprilaku yang sesuai dengan syariah ajaran Islam atau praturan-peraturan yang bersumber dari akidah Islam. Seorang Muslim juga harus melaksanakan tindakan yang terkatogeri wajib atau diperintahkan, sunnah atau dianjurkan, mubah atau yang diperbolehkan, dan tidak akan melakukan yang haram atau yang dilarang. Seperti malakukan yang diperintahkan yaitu mendirikan shalat fardu dan shaum (puas) Ramadhan, menunaikan zakat, menutupi aurat. Melakukan yang dianjurkan termasuk berdakwah, menyerukan amar makruf (menyuruh kepada kebaikan) dan menyeruhkan nahi mungkar (menyeruh untuk meninggalkan kemungkaran), bersedekah, serta berbuat baik terhadap sesama insan manusia.

Terkait hal yang sangat diperintahkan buat umat Muslim adalah maklumat untuk menutup aurat bagi kaum Muslimah baik dengan kerudumg (yang menutup kepala dan dada) 
serta jilbab (yang menutup seluruh tubuh kecuali wajah dan telapak tangan), maka bagi seorang Muslimah menutup aurat dengan memakai kerudung dan jilbab adalah salah satu pembuktian keimanan kepada Allah SWT dan Rasulullah SAW, oleh sebab itu Allah SWT mewanti-wanti (memberikan peringatan) kepada umat Islam supaya jangan memilih jalan menuju sang Maha Pencipta selain ajaran Islam, supaya tidak terpengaruh oleh propaganda kelompok pemuja kebebasan dan feminis supaya para perempuan Muslimah melepas jilbab, serta jangan juga tergiur dengan gaya hidup bebas yang sangat bertentangan dengan nilainilai ajaran Islam sebagaimana di tegaskan Allah SWT dalam surah al-An'am ayat 153 yang berbunyi sebagai berikut :

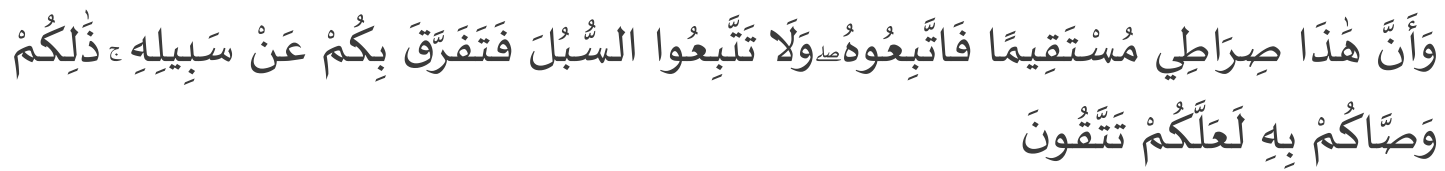

Artinya:

"Dan bahwa (yang Kami perintahkan ini) adalah jalanKu yang lurus, Maka ikutilah Dia, dan janganlah kamu mengikuti jalan-jalan (yang lain), karena jalan-jalan itu mencerai beraikan kamu dari jalanNya yang demikian itu diperintahkan Allah agar kamu bertakwa”. \{Qs. alAn'am/06:153\}

Para mufassir, ada yang menafsirkan bahwa kata "dan bahwa" dibaca dengan fathah pada huruf hamzah dengan memperkirakan adanya huruf lam, dan dibaca dengan kasrah sebagai awal kalimat baru "ini" yakni yang kuperintahkan jilbab atau kerudung saat ini sudah menjadi tren global, termasuk di Indonesia negeri dengan penduduk Muslim terbesar. Pada zaman dahulu betjilbab sangat diidentikan sebagai pakaian para santriwati di pesantrenpesantren, yang pada awal zaman milinium sering dianggap orang-orang yang memakai sering dikesankan sebagai kampungan dan sering dianggap ketinggalan zaman. Namun pada saat ini jilbab sudah menjadi populer dan memasyarakat, bahkan di ruang-ruang publik dan dimana saja sering kita lihat perempuan-perempuan Muslimah yang menggunakan jilbab, dimana jilbab sudah cukup populer di masyarakat sehingga mulai dari anak kecil hingga nenek-nenek memakai jilbab, mulai dari kampung-kampung kecil hingga kota-kota besar juga menggunakan jilbab, bahkan gaya menutup aurat yang diperkenalkan Islam ini sudah meningkat atau naik kelas, yang mana jilbab tidak lagi pakaian kampungan yang selama ini diperspektifkan oleh sebagaian orang tetapi sudah menjadi gaya hidup para istri pejabat.

Apabila dikaji kebelakang, bahwa jilbab dalam lintasan sejarah di Indonesia pada awalnya dikenal sebagai kerudung untuk menutupi rambut perempuan, dan diberbagai negara Muslim termasuk pakaian sejenis jilbab dikenal dengan beberapa istilah seperti chador di 
Iran, pardeh di India dan Pakistan, milayat di Libya, abaya di Irak, charshaf di Turki, dan hijab di beberapa negara Arab-Afrika seperti di Mesir, Sudan dan Yaman.

Maka dari itu, banyak anggapan-anggapan bahwa terlepas dari istilah yang digunakan selama ini sebenarnya hijab (jilbab) bukanlah manipulasi atau hal yang dimonopoli oleh Islam. Menurut Nasaruddin Umar dalam tulisannya, hijab sudah dikenal sebelum adanya agama-agama Samawi yaitu Yahudi dan Nasrani atau Kristen, bahkan Nasruddin Umar menyebutkan bahwa pakaian yang menutupi kepala dan tubuh perempuan sudah menjadi wacana dalam Code Bilalama tahun 3.000 SM, kemudian berlanjut di dalam Code Hammurabi tahun 2.000 SM dan Code Asyiria tahun 1.500 SM. Bahkan ketentuan-ketentuan penggunaan jilab sudah dikenal di berbagai kota tua yang tidak terkecuali Mesopotamia, Babilonia dan Asyria.

\section{B. Sejarah Cadar}

Cadar sudah muncul sebelum diutusnya Rasulullah SAW ke Jazirah Arab, ${ }^{2}$ dalam catatan sejarah cadar pertama kali hadis di Persia Sassan Iran yang mewajibkan para perempuan untuk menutup wajahnya. ${ }^{3}$ Karena baginya nafas perempuan tidak suci dan menjadi noda bagi api yang dijadikan mereka sesembahan. Sehingga perempuan wajib menutup wajahnya dengan apapun itu. Juga telah lama diterapkan di daerah Romawi yang memingit perempuan di dalam rumah, ${ }^{4}$ yangmana rumah laki-laki dan perempuan dipisahkan sehingga laki-laki memiliki tempat tinggal sendiri begitu juga dengan perempuan mempunyai rumah sendiri. ${ }^{5}$

Sekalipun demikian, dalam Islam cadar dipandang oleh sebagian ulama adalah merupakan bagian dari syariat Islam dan sudah diamalkan para isteri Rasulullah SAW, bahkan sebagian ulama beranggapan bahwa untuk isteri Rasulullah SAW sangat dianjurkan atau diwajibkan sedangkan untuk isteri kaum Muslimin lainnya tidak begitu diwajibkan. Alasannya, dikarenakan ketika itu banyak isteri sahabat yang tidak menggunakan cadar dan Rasulullah SAW pun tidak menegur mereka, sehingga sebagian ulama beranggapan bahwa cadar hanya diperuntukkan kepada isteri-isteri Rasulullah SAW saja. Sebab menutup aurat adalah merupakan fitrah manusia sebagaimana telah diaktualisasikan oleh nabi Adam a.s dan istrinya Hawa. ${ }^{6}$ 
Namun mengenai statuta cadar ini, para ulama masih berbeda pendapat dalam melihat hal ini yang mana sebagaian ulama berpendapat wajib memakai cadar dengan rangkaian dalil kuat yang mana menurut mereka bahwa jilbab hanya menutupi aurat secara umum atau standar maka untuk lebih bagus menggunakan cadar guna mempermantap dalam berhijab (menutupi diri dari laki-laki). Berbeda dengan ulama-ulama yang beranggapan bahwa tidak wajib menggunakan cadar dengan rangkaian dalil-dalil yang kuat juga salah satunya adalah tentang atauran nash tentang menutup aurat yang menunjukkan bahwa wajah dan telapak tangan perempuan tidak termasuk aurat yang harus ditutup.

\section{Pengertian dan Batasan Aurat Wanita}

Kata aurat berasal dari bahasa Arab yaitu جسع (awrah), yang secara literasi berarti celah, kekurangan, nuqsan atau ayb (cacat), atau bisa juga didefenisikan mustaqbah atau qubh yaitu sesuatu yang jelek serta memalukan apabila terbuka alias tidak ditutup. Namun sebagian ulama juga berpendapat, bahwa kata aurat berasal dari bahasa Arab سعץ (awara), yang bermakna hilang perasaan. Apabila kata ini dikaitkan dengan mata.

Terlepas dari kontroversi mengenai kata aurat di atas, bahwa prinsip berpakaian dalam Islam dikenakan oleh seseorang sebagai ungkapan ketaatan dan ketundukan kepada Allah SWT, maka karena itu berpakaian terhadap Muslim maupun Muslimah memiliki nilai ibadah sehingga yang memakainya berhak memperoleh pahala asal pakaian tersebut sesuai dengan syariat Islam. Untuk itu, dalam berpakaian pun seorang Muslim harus senatiasa mengikuti aturan-aturan yang telah ditentukan Allah SWT dalam al-Qur'an.

Sekalipun dalam berpakaian, bahwa pakaian seseorang tidak mungkin dapat menentukan kepribadiannya secara mutlak, namun sedikit kecil dari cara berpakaian seseorang dan dari pakaina yang digunakannya dapat mencerminkan kepribadiannya, termasuk apabila ia menggunakan pakaian islami makan akan mencerminkan kepribadian Islam. Lebih dari itu, pakaian yang dikenakan seseorang akan berpengaruh terhadap tindakan lawan bicara terhadapnya, sepertia kepribadian Islam yang dipancarka seseorang akan memancarkan gambaran baik dan kesempurnaan diri seseorang. Oleh karena itu, Islam memberikan arah dan aturan bagaimana cara berpakaian dan pakaian-pakaian sebagaimana ditegaskan Allah SWT dalam surah an-Nur ayat 31 yang berbunyi sebagai berikut : 


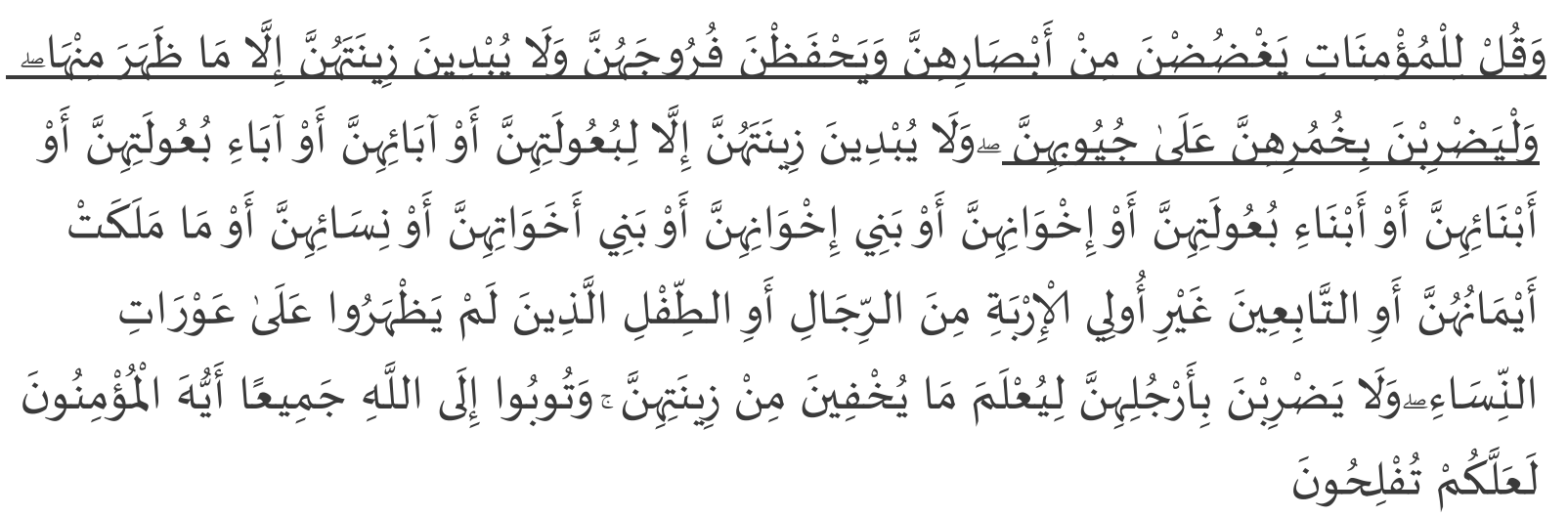

Artinya:

Katakanlah kepada wanita yang beriman: "Hendaklah mereka menahan pandangannya, dan kemaluannya, dan janganlah mereka menampakkan perhiasannya, kecuali yang (biasa) nampak dari padanya. Dan hendaklah mereka menutupkan kain kudung kedadanya, dan janganlah menampakkan perhiasannya kecuali kepada suami mereka, atau ayah mereka, atau ayah suami mereka, atau putera-putera mereka, atau putera-putera suami mereka, atau saudara-saudara laki-laki mereka, atau putera-putera saudara lelaki mereka, atau puteraputera saudara perempuan mereka, atau wanita-wanita islam, atau budak-budak yang mereka miliki, atau pelayan-pelayan laki-laki yang tidak mempunyai keinginan (terhadap wanita) atau anak-anak yang belum mengerti tentang aurat wanita. Dan janganlah mereka memukulkan kakinyua agar diketahui perhiasan yang mereka sembunyikan. Dan bertaubatlah kamu sekalian kepada Allah, hai orang-orang yang beriman supaya kamu beruntung." \{Qs. an-Nur/24: 31$\}$

Kata khumur adalah jamak dari khimar, dalam ayat diatas menegaskan bahwa khumur itu dijulurkan ke dada-dada mereka sehingga tertutuplah rambut, leher, dan anting-anting mereka. Berarti hilang potensi atau khasiat pandangannya atau buta tetapi biasanya ia hanya digunakan bagi yang buta sebelah. Namun dalam surat an-Nur ayat جسع 58 , oleh sebagaian ulama tafsir mengartikannya sebagai sesuatu dari anggota tubuh manusia yang akan membuat malu apabila dipandang.

Sedangkan dalam surah al-Ahzab ayat 13, جسع diartikan sebagai para ulama sebagai cela yang terbuka terhadap musuh, atau cela yang memberikan probality kepada orang lain mengambil kesempatan. Dari sini disimpulkan bahwa جسع adalah mengandung sesuatu yang buruk, atau jika ia dilihat akan menampakkan bahaya atau rasa malu. Maka secara umum dapat dirangkup sebuah defenisi dari aurat yaitu bagian tubuh manusia yang tidak boleh terlihat atau diperlihatkan kepada orang lain, sebab dapat melahirkan aib atau rasa malu. Namun untuk mengetahui lebih jelas mengenai aurat ini, bahwa menurut jumhur ulama (mayoritas ulama) menyebutkan bahwa dalam Islam membedakan aurat laki-laki dengan perempuan. 
Aurat perempuan lebih komplek daripada aurat laki-laki, mengenai aurat ini secara spesifik banyak ditegaskan dalam beberapa dalil nash, yang mana apabila ditilih lewat ilmu kebahasaan bahwa istilah aurat adalah ثيع وا"اصثَ (sesuatu yang cacat) atau قتى واخثقرسي. (menjijikkan) Sedangkan menurut istilah, term aurat merujuk terhadap bagian-bagian tubuh manusia yang harus ditutupi/tidak boleh terlihat secara umum saat di luar rumah ataupun ketika shalat, kecuali wajah dan dua telapak tangan.

Namun, definisi ini masih bersifat umum mencakup laki-laki Muslim dan perempuan Muslim, di beberapa kitab fikih para fuqaha' (ulama-ulama fikih) meneliti persoalan aurat didalam menunaikan shalat, bahkan menurut para ulama menjadikan aurat dalam shalat dijadika ulama fikih sebagai alasan dalam berbusana atau berpakaian Muslim, sekalipun ada sebagaian ulama fikih yang memisahkan aurat dalam shalat dan aurat di luar shalat.

Persoalan aurat ini, sudah menjadi perdepatan yang panjang dari dulu hingga sekarang bahkan sekarang sudah merebah menjadi cadar bentuk lain dari model jilbab yang sekarang menuai kontroversi di kalangan para tokoh agama Indonesia. Kendatipun demikian, mayoritas ulama fikih sepakat bahwa aurat seorang Muslimah adalah seluruh tubuh kecuali wajah dan dua telapak tangan adalah merupakan aurat yang wajib ditutupi sebagaimana ditegaskan Allah SWT dalam surat an-Nur 31 yang sudah diuraikan di atas. Yang diperbolehkan terlihat hanyalah cincin yang melekat di jari, setiap Muslimah sudah seyogianya menyembunyikan gelang tangan, gelang kaki, kalung, mahkota, selempang, dan anting-anting karena semua perhiasan ini terletak pada bagian betis, leher, kepala, dada dan telinga yang merupakan bagian tubuh yang tidak diperbolehkan untuk diperlihatkan kecuali kepada orang-orang yang dikecualikan.

Selain itu, para ulama juga membedakan pendapat dalam memahami lafadz sأثرسا pada kalimat 'Janganlah mereka menampakkan perhiasannya kecuali yang biasa terlihat', perbedaan itu terjadi di seputar apakah lafadz أُثرسا menunjukkan pada anggota badan tertentu saja, atau seluruh anggota badan tidak boleh terlihat. Adapun ulama fikih yang berbeda pendapat terbut mengatakan bahwa lafadz عأثرسا dalam ayat di atas adalah meliputi seluruh anggota tubuh sebagai aurat sebagaimana diperkuat oleh firman Allah SWT dalam surah al-Ahzab ayat 59 yang berbunyi sebagai berikut :

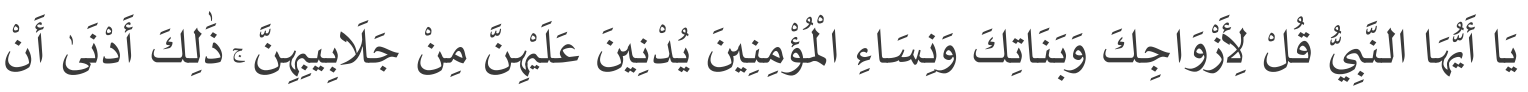

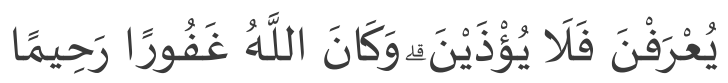

Artinya: 
Wahai Nabi: katakanlah kepada isteri-isterimu, anak-anak perempuanmu dan isteri-isteri orang mukmin: "hendaklah mereka mengulurkan jilbabnya ke seluruh tubuh mereka". Yang demikian itu supaya mereka lebih mudah untuk dikenal. Karena itu mereka tidak diganggu dan Allah adalah Maha Pengampun lagi Maha Penyayang.” \{Qs. al-Ahzab/33:59\}

Sedangakan ulama fikih yang lainnya, berargumentasi bahwalafadz عأثرسا kan hanya anggota badan tertentu saja, dengan kata lain ada anggota tubuh yang boleh ditampakkan, seperti wajah dan dua telapak tangan. Pendapat ini berasal dari pendapat sebagian shahabat, seperti Aisyah, Ibnu Abbas, dan Ibnu Umar. Dalam penilaian Ibnu Jarir Ath-Thabary sebagaimana disebutkan dalam kitab tafsirnya Jami' Al-Bayan fi Tafsir AlQur`an, pendapat yang paling mendekati kebenaran adalah yang mengatakan lafadz adalah anggota tubuh tertentu saja yaitu dengan mengecualikan wajah dan dua telapak tangan. Imam Al-Qurthubi memperluas batasan pengecualian aurat perempuan mencakup wajah dan tangan sampai pertengahan lengan sehingga aurat perempuan ketika melaksanakan shalat adalah seluruh anggota badan kecuali wajah dan telapak tangan. Hal ini sebagaimana terungkap dalam kandungan makna ayat al-Qur'an yang dijadikan pedoman bagi para ulama untuk menjustifikasi batasan aurat yang harus ditutupi saat melaksanakan shalat.

Apabila dikaji lebih dalam mengenai batasan aurat, terungkap bahwa batasan aurat yang diberikan para ulama fikih lebih ditujukan kepada aurat perempuan, dengan tidak menafikkan aurat laki-laki dalam melaksanakan shalat. Jadi, yang dimaksud dengan apa yang tampak dari perempuan berupa wajah dan dua telapak tangan adalah kedua anggota tubuh yang biasa terlihat dari kalangan Muslimah dalam ibadah-ibadah seperti haji dan shalat. Kedua anggota tubuh ini lumrah terlihat pada masa Rasulullah SAW, pada saat turunnya ayat al-Qur`an. Di samping itu terdapat alasan lain yang menunjukkan bahwa seluruh tubuh perempuan adalah aurat kecuali wajah dan dua telapak tangan, karena sabda Rasulullah SAW kepada Asma’ binti Abu Bakar “Dari „Aisyah RA, ia berkata : Sesungguhnya Asma" binti Abu Bakar datang menghadap Rasulullah SAW dengan berpakaian tipis, maka Rasulullah SAW berpaling dan bersabda, "Hai Asmae! Sesungguhnya seorang perempuan apabila sudah haid, tidak boleh terlihat padanya melainkan ini dan ini”, beliau sambil mengisyaratkan pada muka dan dua tapak tangan beliau”.

Selanjutnya konteks aurat perempuan di luar shalat, para ulama Hanafiyah, Malikiyah dan sebagian Syafi'iyah berpendapat bahwa aurat perempuan yang harus ditutup adalah seluruh tubuh kecuali wajah dan telapak tangan. Namun Imam Hanafi dan Imam Malik berpendapat bahwa selain muka dan telapak tangan, yang boleh terlihat juga adalah kedua 
betis perempuan. Sedangkan Imam Hanbali mempunyai pandangan yang lebih ketat dan sangat menjaga, bahwa seluruh tubuh perempuan adalah aurat, termasuk kedua telapak tangan. Dan yang boleh terlihat pada sisi perempuan hanya wajah saja. Meskipun terjadi perbedaan dalam menentukan batas aurat bagi perempuan, tetapi para ulama fikih telah sepakat bahwa menutup aurat hukumnya fardhu. Sehingga orang yang tidak menutup aurat ketika shalat maka shalatnya menjadi tidak sah, dan ketika ke luar rumah membuka aurat maka ia akan berdosa.

Kewajiban menutup aurat perempuan, bukanlah berarti mempersulit kaum wanita untuk hidup dan berinteraksi dalam kehidupan sosial, sebab dalam Islam juga memberikan keringanan kepada perempuan untuk membuka bagian kepalanya ketika berada di rumah karena dirumah tidak ada ajnabi (orang asing).

Hironisnya, banyak perempuan Muslim yang mengenakan pakaian pendek hingga lutut dan pahanya kelihatan saat duduk yang merupakan perbuatan yang meniru perempuanperempuan kafir yang sangat diharamkan dalam ajaran Islam, sekalipun busana tersebut dipakai dihadapan sesama perempuan. Seorang perempuan tidak hanya dilarang untuk melihat perempuan sama perempuan apalagi dilihat laki-laki. Dengan kata lain, seorang lakilaki diperkenankan melihat aurat perempuan dan perempuan juga tidak diperkanankan melihat aurat laki-laki, begitu pula dengan aurat sesama perempuan ataupun aurat sesama laki-laki sama-sama tidak diperkenankan saling membuka aurat dengan dalih satu jenis klamin.

Beranjak dari persoalan berpakaian, satu lagi hal yang harus diketahui setiap kaum Muslimah adalah mengenai bagian mana tubuh perempuan yang harus ditutupi sehingga jelas batasan aurat perempuan, maka mengenai ini para ulama membagi batasan auarat menjadi 3 bagaian sebagai berikut :

1. Dihadapan suami

Apabila berada dihadapan suami, seorang perempuan bisa memperlihatkan seluruh badan tanpa kecuali secata totalilas.

2. Dihadapan mahramnya 
Apabila seorang perempuan berada dihadapan mahram yaitu orang-orang yang disebut dalam surah an-Nur ayat 31 dan surah an-Nisa ayat 32 .

3. Dihadapan laki-laki selain suami dan ajnabi (mahramnya).

Apabila seorang perempuan berada dihadapan laki-laki selain suami dan ajnabi (mahramnya) maka aurat perempuan tersebut adalah seluruh tubuh kecuali wajah dan telapak tangan.

\section{Jenis-Jenis Pakaian Prempuan dalam Syariat Islam}

Adapun yang disebut pakaian, adalah barang yang dipakai oleh tubuh seperti baju, celana dan sebagainya, pakaian secara umum dipahami sebagai alat sebagai pelindung badan atau suatu fasilitas untuk memperindah penampilan, namun selain itu, pakaian pun dapat berfungsi sebagai alat komunikasi yang non verbal, sebab pada hakikatnya pakaian juga mengandung simbol-simbol yang memiliki beragam makna.

Dalam Islam, pakaian merupakan simbol identitas, jati diri, kehormatan dan kesederhanaan bagi seseorang untuk melindungi diri dari berbagai bahaya yang dapat mengancam kehidupan seseorang. Oleh sebab itu, pakaian dalam pandangan Islam mempunyai kriteria yang sangat jauh dari tujuan ekonomi apalagi tujuan yang mengarah pada pelecehan penciptaan makhluk Allah SWT.

Menurut ajaran Islam, pakaian tidak hanya bertujuan untuk melindungi diri dari sesuatu hal yang dapat mengancam saja tetapi untuk menutup aurat termasuk harus menggunakan khimar yaitu kain yang menutup kepala, leher dan dada, bahkan sebagian ulama mengatakan bahwa sesuatu itu disebut jilbab atau khimar apabila kain tersebut sampai hingga kancing baju yang paling bawah. Tidak hanya itu, para ulama juga berpendapat bahwa kain tersebut disebut khimar dengan syarat tidak terbuka atau tidak tembus pandang, dan tidak ketat, maka dalam kamus al-Mu'jam al-Wasith disebutkan bahwa jilbab memiliki beberapa makna, yang antara lain yaitu $:^{7}$

1. Qomish (sejenis jubah);

2. Kain yang menutupi seluruh badan;

3. Khimar (kerudung);

4. Pakaian atasan seperti milhafah (selimut);

5. Semisal selimut yang dipakai seorang perempuan untuk menutupi tubuhnya. ${ }^{8}$ 
Sedangkan menurut istilah, menurut Ibn Hazm r.a mendefenisikan bahwa jilbab berasal dari bahasa Arab yang disebutkan oleh Rasulullah SAW sebagai pakaian yang menutupi seluruh badan bukan hanya menutupi sebagiannya. Sedangkan Ibnu Kasir, mendefenisikan jilbab adalah semacam selendang yang dikenakan di atas khimar yang sekarang ini sama fungsinya seperti izar (kain penutup). Begitu juga, Syaikh bin Baz mendefenisikan jilbab adalah kain yang diletakkan di atas kepala dan badan di atas kain dalaman, sehingga dapat disimpulkan bahwa jilbab adalah kain yang dipakai perempuan untuk menutupi kepala, wajah dan seluruh badan sedangkan kain untuk menutupi kepala disebut khimar. Maka seyogianya, seorang perempuan mesti menutup auratnya dengan jilbab dan apabila memungkinkan juga memakai rida' (selendang) yang dipakaikan di atas khimar (kerudung) seperti abaya (pakaian perempuan-perempuang negara Saudi Arabia).

Berbicara tentang jilbab, apabila ditili dari segi perspektif Islam kata jilbab memang ada dipakai didalam al-Qur'an dan hadis namun mengenai maksud kata jilbab tersebut dikembalikan pada maksud yang dipahami oleh masyarakat ketika kata itu diturunkan/diungkapkan, sebagaimama Ibnu Abbas meriwayatkan bahwa yang dimaksud jilbab adalah baju luar yang berfungsi menutupi tubuh dari atas sampai bawah atau ketanah.

Sedangkan dalam kamus Arab yang berjudul Al-Muhith, dijelskan bahwa jilbab bermakna pakaian yang lebar bagi perempuan yang menutupi tsiyab atau mihnah yaitu pakaian harian yang biasa dipakai ketika berada di dalam rumah, yang bentuknya seperti malhafah (kain penutup dari atas kepala sampai ke bawah). Begitu juga sama dengan apa yang disebutkan oleh al-Jauhari dalam kitabnya yang berjudul Ash Shihah.

Sedangkan yang disebut dengan pakaian luar adalah pakaian yang sekalipun dibuka tidak akan menampakkan aurat termasuk bentuk tubuhnya, maka pakaian luar ini sangat dianjurkan terhadap perempuan, sekalipun perempuan yang manopause (perempuan yang sudah tidak mempunyai keinginan seksual) juga semestinya memakai jilbab. Bahkan lebih dari itu, bisa saja menggunakan cadar untuk menutupi dari pamer kecantikan dan tidak tabarruj (pamer perhiasan). ${ }^{9}$

Sebenarnya dalam Islam, dalam rangka menutupi aurat mengenai model jilbabnya tidak ada model baku yang diwajibkan sehingga mengenai model boleh saja disesuaikan dengan tradisi masyarakat sepanjang tidak bertentangan dengan syariah Islam, begitu juga dengan pakaian apa model pakaiannya dibolehkan dalam Islam asal model pakaian tersebut tidak menampakkan bentuk tubuh seperti daster, celana ketat panjang dan tabarruj lainnya. maka pakain yabrruj ini tidak diperkenankan dipakai tampa ada pakaian luar yang menutupinya 
sehingga benar-benar menutup aurat sehingga tidak pantas seorang Muslimah yang hanya menggunakan daster dan celana ketat sebagai pakaian sehari-harinya tanpa ada pakaian luarnya, bahkan menurut sebagian ulama setiap Muslimah harusnya dalam setiap hari menggunakan hijab syar'i yang sesuai dengan tutunnan syariat yang sebaiknya menggunakan tiga lapis atau jenis pakaian ketika di hadapan laki-laki non mahrom yaitu kerudung, mihnah dan jilbab.

Selanjutnya, mengenai sanksi perempuan-perempuan yang tidak memakai cadar juga tidak ada aturan yang jelas dan tegas disebutkan dalam al-Qur'an dan sunnah sehingga menunjukkan bahwa cadar bukanlah merupakan kewajiban bagi para Muslimah namun sudah menjadi anjuran dan diperbolehkan saja. Kecuali orang-orang yang membuka aurat seperti para Muslimah yang memamerkan aurta di tempat umum seyogianya harus dihukum dengan hukuman ta'zir (hukuman yang ditentukan pemerintah) sebagai teguran dan peringatan agar yang bersangkutan dan Muslimah yang lainya tidak melakukannya perbuatan tersebut di kemudian hari, ${ }^{10}$ terkecuali saat bersama suami isteri saja dirumah ${ }^{11}$ maka seorang isteri bisa saja membuka auratnya dengan menggunakan daster dan celana ketat tersebut.

\section{E. Penutup}

Cadar sudah muncul sebelum diutusnya Rasulullah SAW ke Jazirah Arab, dalam catatan sejarah cadar pertama kali hadis di Persia Sassan Iran yang mewajibkan para perempuan untuk menutup wajahnya, dan ada juga yang beranggapan bahwa cadar pertama kali hadir di daerah Romawi.

Cadar adalah kain yang digunakan untuk menutup hidung dan anggota tubuh yang berada dibawah lekuk mata, yangmana hal ini tidaklah merupakan hal yang asing pada masa kenabian, para Muslimah sudah terbiasa menggunakannya baik sebagian isteri para sahabat termasuk ummahatul Mukminin (para isteri Rasulullah SAW) sehingga kebanyakan orang beranggapan bahwa cadar tersebut sudah menjadi hal yang disyariatkan (diutamakan dalam Islam).

Namun apabila cadar dikatakan wajib, hal ini juga diperselisikan tokoh Muslim sebab pada zaman sahabat masih ada sebagian sahabat dan isteri sahabat yang masih membuka wajah atau tidak menggunakan cadar dan Rasulullah SAW pun tidak menegur mereka, sehingga sangat memungkinkan bahwa pada masa itu cadar tidak menjadi kewajiban tetapi 
masih berupa hal diperbolehkan, dan sekarang tidak hanya untuk menutup aurat tetapi menambah kecantikan terbukti ada sebagian orang terlihat lebih cantik saat menggunakan hijab.

\section{End Note :}

${ }^{1}$ Muhammad bin Jarir al-Tabari, Jami' al-Bayan fi Ta'wil al-Quran, Juz. 12, (Bairut: Mu'assasah alRisalah, 2000), hlm. 351.

${ }^{2}$ Tahir Abd al-Latif 'Iwad, Muhadarat Fi al-Adab al-Jahili, (Kairo: Jami'ah al-Azhar Kulliyah al-Dirasat al-Islamiyah wa al-'Arabiah, 2004), 49.

${ }^{3}$ Murtadha Muthahari, Gaya Hidup Wanita Islam, ter. Agus Efendi, Alwiyah Abdurrahman, (Bandung, Mizan, 1990), hlm. 34.

${ }^{4}$ Hasan al-'Audah, al-Mar'ah al-'Arabiyah Fi al-Din wa al-Mujtama', (Bairut: al-Ahaly, 2000), 101-102

${ }^{5}$ Muhammad Sayyid Tantawi, al-Tafsir al-Wasit Li al-Quran al-Karim, Juz. 11, (Kairo: Dar alSa'adah, 1985), hlm. 207.

${ }_{7}^{6}$ M. Quraish Shihab, Jilbab Pakaian Wanita Muslimat, (Jakarta: Lentera Hati, 2014), hlm. 48.

${ }^{7}$ Abu Ishaq Ahmad bin Muhammad al-Tha'labi al-Naisaburi, Al-Kasyf wa al-Bayān 'An Tafsiral-Qurān, Juz. 08, (Bairut: Dār Ihya' al-Turath al-'Arabi, 2002), hlm. 35.

${ }^{8}$ Abdullah bin Abdul Aziz Ali Sa'ud, Al-Qurān wa TarjamatuMa'ānihi Ila Al-Lughah Al-Indonisiyah, (Saudi: Majma' Malik Fahd Li Thibā'ah alMushaf al-Syarīf, 1418 H), hlm. 223.

${ }^{9}$ Nasaruddin Umar, Antropologi Jilbab, pada Jurnal Kebudayaan dan Peradaban Ulumul Qur'an, no. 5, Vol.VI, 1996, hlm. 36.

${ }^{10}$ Hendra Gunawan, penerapan Hukuman Ta'zir Di Indonesia (Suatu Analisis Terhadap Penerapan Hukuman Di Lapas Kota Padangsidimpuan) pada Jurnal Fitrah: Jurnal Kajian Ilmu-ilmu Keislaman Volume 4 Nomor 2 Edisi Juli-Desember 2018, hlm. 359-374.

${ }^{11}$ Faraj 'Ali al-Sayyid 'Anbar, Muh\}ad\}arat fi al-Ahwal al-Shakhs\}iyah, (Kairo: Jami'ah al-Azhar Kulliyah al-Dirasat al-Islamiyah wa al-'Arabiah, 2008), 91-92. 


\section{DAFTAR PUSTAKA}

'Anbar, Faraj 'Ali al-Sayyid,. Muhadarat fi al-Ahwal al-Shakhsiyah, Kairo: Jami'ah al-Azhar Kulliyah al-Dirasat al-Islamiyah wa al-'Arabiah, 2008.

al-'Audah, Hasan,. al-Mar'ah al-'Arabiyah Fi al-Din wa al-Mujtama', Bairut: al-Ahaly, 2000.

al-Latif 'Iwad, Tahir Abd,. Muhadarat Fi al-Adab al-Jahili, Kairo: Jami'ah al-Azhar Kulliyah al-Dirasat al-Islamiyah wa al-'Arabiah, 2004.

al-Naisaburi, Abu Ishaq Ahmad bin Muhammad al-Tha'labi,. Al-Kasyf wa al-Bayān 'An Tafsiral-Qurān, Juz. 08, Bairut: Dār Ihya' al-Turath al-'Arabi, 2002.

al-Tabari, Muhammad bin Jarir,. Jami' al-Bayan fi Ta'wil al-Quran, Juz. 12, Bairut: Mu'assasah al-Risalah, 2000.

Gunawan, Hendra,. penerapan Hukuman Ta'zir Di Indonesia (Suatu Analisis Terhadap Penerapan Hukuman Di Lapas Kota Padangsidimpuan) pada Jurnal Fitrah: Jurnal Kajian Ilmu-ilmu Keislaman Volume 4 Nomor 2 Edisi Juli-Desember 2018.

Muthahari, Murtadha,. Gaya Hidup Wanita Islam, ter. Agus Efendi, Alwiyah Abdurrahman, Bandung, Mizan, 1990.

Sa'ud, Abdullah bin Abdul Aziz Ali,. Al-Qurān wa TarjamatuMa'ānihi Ila Al-Lughah AlIndonisiyah, Saudi: Majma' Malik Fahd Li Thibā'ah alMushaf al-Syarīf, 1418 H.

Shihab, M. Quraish, Jilbab Pakaian Wanita Muslimat, Jakarta: Lentera Hati, 2014.

Tantawi, Muhammad Sayyid,. al-Tafsir al-Wasit Li al-Quran al-Karim, Juz. 11, Kairo: Dar alSa'adah, 1985.

Umar, Nasaruddin,. Antropologi Jilbab, pada Jurnal Kebudayaan dan Peradaban Ulumul Qur'an, No. 5, Vol.VI, 1996. 